\title{
TESES
}

\section{Cenários modernos e pós-modernos no Brasil: juventude, política e rock-and-roll}

Rubens de Freitas Benevides

Curso: Doutorado em Sociologia

Data da defesa: 25 de junho de 2008

Orientadora: Prof ${ }^{\mathrm{a}} \mathrm{Dr}^{\mathrm{a}}$ Mariza Veloso Motta Santos

\section{Resumo}

Entre as principais motivações desta pesquisa encontra-se o fato de que, em menos de uma década, a imagem (e provavelmente a auto-imagem) da cidade de Goiânia sofreu uma transformação radical. O ano de 1995 pode ser considerado como um marco dessa mudança e dois fatos ocorridos na cidade foram os seus deflagradores. O primeiro trata da tentativa do então prefeito da cidade de outorgar o título de "Goiânia, Capital Country" à capital do estado de Goiás. Contudo, no mesmo ano, outra expressão cultural passou a adquirir visibilidade e a dar notoriedade a Goiânia: trata-se da cena de rock independente de Goiânia, cujo marco inicial é o primeiro Goiânia Noise Festival. A cena independente notabilizou Goiânia no contexto nacional como a "capital do rock independente", sem qualquer iniciativa ou apoio público ou governamental para tanto, mediante uma forma de produção cultural totalmente improvável em Goiás, o rock-and-roll. O problema deste trabalho consiste em como a cultura musical roqueira da cena independente se expressa politicamente. A resposta deve passar, necessariamente, pelo conceito 
de "performatividade", pois esta se apresenta, em sua forma forte, por meio dos processos de identificação, enquadrados pelo "imperativo social do desempenho". As performances realizadas pelos músicos no palco possibilitam a identificação com posições normativas excluídas e, neste sentido, são homólogas às dos atores coletivos no espaço público. Em Goiânia, isso pode ser verificado pela presença significativa de homossexuais nas mais diversas práticas existentes na cena independente, desde produtores e músicos até o público, segundo relatos de alguns entrevistados. Em uma cidade cuja cultura é identificada, local e nacionalmente, com o estilo country, com as raízes rurais e com tradições machistas, a produção cultural e estética, o estilo, as práticas estabelecidas, que são completamente fora dos padrões goianienses, ao se constituírem como totalmente inclusivas das minorias e identidades marginalizadas e discriminadas, deixam antever a faceta política progressista da cena independente de Goiânia, que denominamos de política da diferença.

Palavras-chave: juventude; identidade; rock-and-roll; política da diferença; "performatividade". 